\title{
Influence of the preparation procedure and crystallite size of Fe-MFI zeolites in the oxidehydration of glycerol to acrolein and acrylic acid
}

Modibo Mounguengui Diallo, Sébastien Laforge, Yannick Pouilloux, Jérôme Mijoin*

Université de Poitiers, CNRS, Institut de Chimie des Milieux et Matériaux de Poitiers (IC2MP), 4 Rue Michel Brunet - TSA 51106, F-86073 Poitiers, France

*Corresponding author: jerome.mijoin@univ-poitiers.fr 


\begin{abstract}
Fe-MFI zeolites are very promising materials for the oxidehydration of glycerol. This work shows that preparation procedure influences product selectivity. Hydrothermal synthesis is more selective to acrylic acid thanks to the $\mathrm{Fe}^{(+\mathrm{III})}$ tetrahedral species in framework position. Conversely, post-synthesis treatment in a fluoride medium generates $\mathrm{Fe}^{(+\mathrm{II})} \mathrm{O}_{\mathrm{x}}$ clusters in extraframework position that increases acrolein selectivity. The reduction of the crystalline size of iron MFI to a nanoscale leads to a highly active, selective and stable catalyst with a stabilized glycerol (40 wt.\% in water) conversion of $90 \%$ and acrolein selectivity of $87 \%$.
\end{abstract}

\title{
Keywords
}

isomorphous substitution, ion exchange, nanosized zeolite, biomass, iron zeolite 


\section{Introduction}

The surplus of available glycerol resulting from the significant surge of biodiesel production encourages its valorisation in various products [1-3]. Transformation of glycerol to acrolein is an attractive alternative route of its usual synthesis from propene. Acrolein is a major chemical product with many industrial applications including proteins (via methionine), polymers or paints (via acrylic acid) [3]. Acrylic acid can be directly produced from glycerol via acrolein. However, this process often requires two catalytic stages: one for glycerol dehydration to acrolein and the other for the subsequent oxidation to acrylic acid (see supplementary material scheme S1).

Zeolites possess large surface area and acid sites in a sufficient amount to achieve the first step of glycerol dehydration to acrolein [3]. The second step (oxidation to acrylic acid) is usually carried out over metal oxide [4,5]. Glycerol conversion and acrolein selectivity were improved using MFI type zeolites with low acidity thus high $\mathrm{Si} / \mathrm{Al}$ ratio [6,7]. However, the main drawback of these materials is the rapid deactivation over time. Nevertheless, several works pointed out that smaller particle size were more suitable to reduce deactivation $[6,8]$. Indeed, many chemicals reactions on nanocrystalline zeolites $(<100 \mathrm{~nm})$ were facilitated because of the large external surface area, which leads to an improved diffusion of the reactants [8-10]. Addition of metals to zeolites also showed a beneficial effect for glycerol dehydration to acrylic acid in one step $[11,12]$. Fe-MFI zeolites are particularly interesting for dehydration processes or biomass conversion [13-15]. It was shown that the preparation procedure influence the formation of different iron species over zeolite, which are redox sites [16]. Our previous studies gave very encouraging results in aerobic condition using postsynthesis isomorphous substitution [17,18]. It was shown that with $0.6 \mathrm{wt} \%$ of iron over MFI zeolite with $\mathrm{Si} / \mathrm{Al}$ ratio of 60 ( $\mathrm{Fe}_{0.6}$-MFI-60), acrolein selectivity reached a stable value of $82 \%$ at $80 \%$ of glycerol (40wt\% in water) conversion after $24 \mathrm{~h}$ of reaction [17]. Otherwise, when adding $4 \mathrm{wt} \%$ of iron over BEA zeolite, a $23 \%$ yield of acrylic acid was achieved in one step oxidehydration of pure glycerol [18], which place these catalysts among the best in the literature. In order to better understand the preparation method as well as to improve results, and for the first time, the influence of preparation procedures of Fe-MFI zeolites was studied to end up, after showing the crucial role of crystallite size, to one of the most active, selective and stable catalytic system to date. 


\section{Experimental}

\subsection{Zeolite preparation}

Five Fe-containing zeolites were prepared by four different procedures with the same targeted iron content $(0.6 \mathrm{wt} \%)$ and were labelled as $\mathrm{Fe}_{\mathrm{X}}-\mathrm{MFI}-\mathrm{Y}-\mathrm{Z}$ with $\mathrm{X}$ the weight amount of iron, $\mathrm{Y}$ the $\mathrm{Si} / \mathrm{Al}$ molar ratio and $\mathrm{Z}$ the preparation procedure. The first catalyst $\left(\mathrm{Fe}_{0.6}-\mathrm{MFI}-45-\mathrm{HS}\right)$ was prepared by hydrothermal synthesis [19] and the four others by postsynthesis preparations: two ( $\mathrm{Fe}_{0.6}-\mathrm{MFI}-60-\mathrm{PS}$ and nanosized $\mathrm{Nc}-\mathrm{Fe}_{0.6}-\mathrm{MFI}-45-\mathrm{PS}$ ) by post synthesis treatment in a fluoride medium [20], one (Fe.6-MFI-60-IE) by ion exchange [16] and the last (Fe.6-MFI-60-Imp) by impregnation [16] (see supplementary material for details).

\subsection{Characterization}

Physical properties were determined by powder X-Ray Diffraction (XRD) analysis on a Panalytical Empyrean diffractometer and by nitrogen adsorption at $-196^{\circ} \mathrm{C}$ on a micromeritics ASAP 2000 device (experimental details are given in supplementary material).

Elemental analyses were achieved by Inducted Coupled Plasma-Optical Emission Spectroscopy (ICP-OES) (see supplementary material for details).

Thermo-programmed desorption of ammonia ( $\mathrm{NH}_{3}-\mathrm{TPD}$ ) was used for the determination of total acidity. The samples were placed in a fixed-bed continuous-flow quartz microreactor inside the furnace (see supplementary material for details).

The Brønsted and Lewis acidity were obtained by pyridine adsorption-desorption on a Nicolet Magna FTIR 550 spectrometer. Firstly, the samples were pressed into thin wafers and activated in situ in the IR cell under vacuum. Afterward, gaseous pyridine was adsorbed at

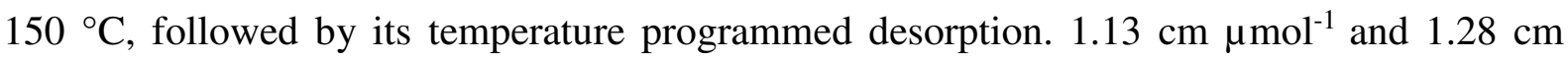
$\mu \mathrm{mol}^{-1}$ were the extinction coefficients used for the quantification of the Brønsted and Lewis acid sites respectively [21].

The temperature programmed reduction (TPR) of the catalysts was completed with a Micromeritics Autochem II analyser in a quartz microreactor. The samples were first pretreated for 2 hours at $500{ }^{\circ} \mathrm{C}$ in Argon $\left(30 \mathrm{~mL} \mathrm{~min}^{-1}\right)$ and cooled down to $40{ }^{\circ} \mathrm{C}$. Then, they were treated under $30 \mathrm{~mL} \mathrm{~min}^{-1}$ of $10 \%$ of $\mathrm{H}_{2}$ in $\mathrm{Ar}$ from 40 to $900{ }^{\circ} \mathrm{C}\left(10{ }^{\circ} \mathrm{C} \mathrm{min}^{-1}\right)$ under a TCD detector monitoring. 
UV-vis analyses were done on a Varian Carry 5000 UV spectrometer (see supplementary material for details).

\subsection{Catalytic tests}

The catalytic oxidehydration of glycerol was carried out at $320^{\circ} \mathrm{C}$ under atmospheric pressure. The catalyst was loaded in a glass reactor $(80 \mathrm{~cm}$ length. $0.6 \mathrm{~cm}$ diameter) on a quartz wool bed using $300 \mathrm{mg}$ of solid (corresponding to a gas hourly space velocity, GHSV, of $2770 \mathrm{~h}^{-1}$ ). The sample was then pre-treated at $400^{\circ} \mathrm{C}$ under $15 \mathrm{~mL} \mathrm{~min}^{-1} \mathrm{~N}_{2}$ for $30 \mathrm{~min}$. The feed was an aqueous solution containing $40 \mathrm{wt} \%$ of glycerol (99\%, Sigma-Aldrich) in water. $0.1 \mathrm{~mL}$ $\min ^{-1}$ of this solution was injected at the head of the reactor with air $\left(15 \mathrm{~mL} \mathrm{~min}^{-1}\right)$ as carrier gas. The products were regularly collected in a condenser $\left(-4^{\circ} \mathrm{C}\right)$ connected to the reactor outlet and analysed by an Agilent Technologies 7820A gas chromatograph with FID detector. The column used was a CBwax $(30 \mathrm{~m}, 0.32 \mathrm{~mm}, 1 \mu \mathrm{m})$. Butanol was used as internal standard. The following equations present the calculation of glycerol conversion, product yield and product selectivity:

$$
\begin{gathered}
\text { Glycerol conversion }(\%)=\frac{[\text { Gly }] \text { input }-[\text { Gly }] \text { output }}{[\text { Gly }] \text { input }} \times 100 \\
\text { Product yield }(\%)=\frac{[\text { Product }]}{[\text { Gly }] \text { input }} \times 100 \\
\text { Product selectivity }(\%)=\frac{\text { Product yield }}{\text { Glycerol conversion }} \times 100
\end{gathered}
$$

\section{Results and Discussion}

\subsection{Physicochemical characterization}

MFI-60 and MFI-45 zeolites have crystallite sizes in the 0.2-1 and 0.045-0.5 $\mu \mathrm{m}$ ranges respectively (measured by transmission electron microscopy).

\subsubsection{Textural properties}

Preliminary physical characterization by XRD (Fig.1) shows by comparison with a calculated diffractogram that hydrothermal synthesis of $\mathrm{Fe}_{0.6}$-MFI-45-HS led actually, without extra phase, to the MFI structure [19]. In addition, post-synthesis preparations ( $\mathrm{Fe}_{0.6}-\mathrm{MFI}-60-\mathrm{PS}$, 
Nc-Fe ${ }_{0.6}$-MFI-45-PS, $\mathrm{Fe}_{0.6}$-MFI-60-IE and $\mathrm{Fe}_{0.6}$-MFI-60-Imp) do not changed the initial MFI structure. Moreover, no other crystalline phase was observed, which suggests the absence of crystallized iron particles and/or that iron was overall well dispersed over materials [16,22]. Nc-Fe ${ }_{0.6}$-MFI-45-PS (Fig.1.e) presents slightly broader diffraction peaks in comparison with other zeolites that indicate, as expected, smaller particles size.

Table 1 presents the properties of the samples derived from $\mathrm{N}_{2}$ adsorption at $-196^{\circ} \mathrm{C}$. Surfaces and pore volumes are similar, but a closer look at materials with the same crystallite size, one can notice a slight decreasing trend from $\mathrm{Fe}_{0.6}$-MFI-45-HS to Fe 0.6 -MFI-60-Imp. Moreover, external surface is halved with respect to $\mathrm{Fe}_{0.6}$-MFI-45-HS $\left(76 \mathrm{~m}^{2} \mathrm{~g}^{-1}\right)$ on $\mathrm{Fe}_{0.6}$-MFI-60-Imp $\left(37 \mathrm{~m}^{2} \mathrm{~g}^{-1}\right)$. Indeed, post-synthesis preparations such as ion exchange and impregnation may generate extra-framework iron species (mostly iron oxides in the case of impregnation), which occupy a part of the external surface and consequently reduces the total available surface area. Conversely, isomorphous substitution (HS and PS) and especially hydrothermal synthesis promotes iron in framework position with tetrahedral coordination that is better dispersed.

Nc-Fe ${ }_{0.6}$-MFI-45-PS has the largest total surface $\left(469 \mathrm{~m}^{2} \mathrm{~g}^{-1}\right)$ due to the more important external surface $\left(88 \mathrm{~m}^{2} \mathrm{~g}^{-1}\right)$, which is correlated to the largest mesopore volume $\left(0.20 \mathrm{~cm}^{3} \mathrm{~g}^{-1}\right.$, see supplementary Fig.S1) and confirm the nanosize of this zeolite as expected by XRD. Pore size distribution profiles shows also the important mesoporosity on nanosized sample when the others are quite similar apart from a few differences inherent to their respective synthesis methods (Fig S2).

\subsubsection{Iron content and acidity}

Iron contents measured by elemental analysis overall confirm the desired value ( $\sim 0.6 \mathrm{wt} . \%)$ whatever the preparation procedure (table 2). $\mathrm{Fe}_{0.6}$-MFI-45-HS has the higher total acidity $\left(402 \mu \mathrm{mol} \mathrm{g}{ }^{-1}\right)$ in agreement with its lower Si/Al ratio (45) and the largest Brønsted acidity $\left(198 \mu \mathrm{mol} \mathrm{g}{ }^{-1}\right)$ caused by the more numerous compensation protons [6]. Total and Brønsted acidity of $\mathrm{Fe}_{0.6}$-MFI-60-PS (301 and $155 \mu \mathrm{mol} \mathrm{g}{ }^{-1}$ ) are slightly lower than that of $\mathrm{Fe}_{0.6}$-MFI45-HS (table 2) because of its higher $\mathrm{Si} / \mathrm{Al}$ ratio (60). Nevertheless, at the same $\mathrm{Si} / \mathrm{Al}$ ratio this acidity was slightly reduced for $\mathrm{Fe}_{0.6}$-MFI-60-Imp (231 and $145 \mu \mathrm{mol} \mathrm{g}{ }^{-1}$ ) and especially

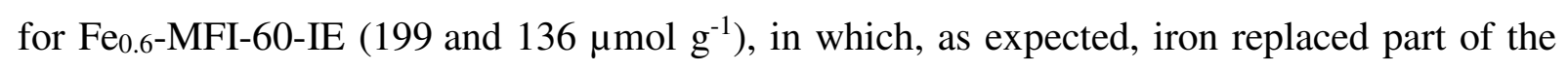


protons [23]. Inversely, over $\mathrm{Fe}_{0.6}$-MFI-60-PS, iron probably substituted a part of aluminium in framework position to end up with a similar acidity [24].

Lewis acidity was also altered (table 2). Ionic exchange and impregnation lead to an increase of Lewis acidity (28 and $38 \mu \mathrm{mol} \mathrm{g} \mathrm{g}^{-1}$ respectively) against only $17 \mu \mathrm{mol} \mathrm{g} \mathrm{g}^{-1}$ for the fluoride treatment (Fe $\mathrm{Fe}_{6}$-MFI-60-PS), which confirms the formation of extra-framework iron species by impregnation ( $\mathrm{Fe}_{0.6}$-MFI-60-Imp) and ionic exchange ( $\left.\mathrm{Fe}_{0.6}-\mathrm{MFI}-60-\mathrm{IE}\right)$ responsible of additional Lewis acidity [14]. Despite the $\mathrm{Si} / \mathrm{Al}$ of 45 , total acidity of $\mathrm{Nc}-\mathrm{Fe}_{0.6}-\mathrm{MFI}-45-\mathrm{PS}$, is only of $310 \mu \mathrm{mol} \mathrm{g}{ }^{-1}$, which suggests a less complete isomorphous substitution and a greater amount of extra-framework iron leading to a higher Lewis acidity $\left(78 \mu \mathrm{mol} \mathrm{g}{ }^{-1}\right)$.

\subsubsection{Determination of iron species by TPR and UV-Vis}

Fig.2 presents the TPR profiles of the different catalysts. Fe 0.6 -MFI-60-IE has mostly one reduction peak at $450^{\circ} \mathrm{C}$, which is assigned to extra-framework $\mathrm{Fe}^{(+\mathrm{III})}$ species in exchange position with a $\mathrm{H}_{2} / \mathrm{Fe}$ ratio of 0.66 close to 0.5 , typical of the octahedral $\mathrm{Fe}^{(+\mathrm{III})}$ to $\mathrm{Fe}^{(+\mathrm{II})}$ species reduction [25]. These species are also found over $\mathrm{Fe}_{0.6}-\mathrm{MFI}-45-\mathrm{HS}$ and $\mathrm{Fe}_{0.6}-\mathrm{MFI}-60-$ PS but in lesser amounts (Fig.2). However, the two latter materials are mainly characterized by the presence of $\mathrm{Fe}^{(+\mathrm{III})}$ species in framework position around $642{ }^{\circ} \mathrm{C}$. Actually, tetrahedral $\mathrm{Fe}^{(+\mathrm{III})}$ are more difficult to reduce than octahedral extra-framework $\mathrm{Fe}^{(+\mathrm{III})}$ species over MFI zeolites as shown by Pérez-Ramirez [26].

The last peak at $789{ }^{\circ} \mathrm{C}$ over $\mathrm{Fe}_{0.6}$-MFI-60-PS is assigned to the total reduction to metallic iron $\mathrm{Fe}^{(0)}$ of $\mathrm{Fe}^{(+\mathrm{II})} \mathrm{Ox}$ species. These species are probably formed by autoreduction of $\mathrm{Fe}^{(+\mathrm{III})}$ in lattice position during calcination procedure and more easily for post-synthesis substituted samples in which iron is certainly less stable [27]. Peaks at 492 and $598{ }^{\circ} \mathrm{C}$ for $\mathrm{Fe}_{0.6}-\mathrm{MFI}-60$ Imp are essentially assigned to extra-framework iron oxides $\left(\mathrm{Fe}^{(+\mathrm{III})} \mathrm{Ox}\right.$ oligomers and/or $\mathrm{Fe}_{2} \mathrm{O}_{3}$ particles) [28-30].

To complete the results of TPR, UV-vis was carried out over Fe 0.6 -MFI-45-HS, Fe 0.6 -MFI-60IE, $\mathrm{Fe}_{0.6}$-MFI-60-PS and Nc-Fe 0.6 -MFI-45-PS (Fig.3).

The presence of octahedral $\mathrm{Fe}^{(+\mathrm{III})}$ in extra-framework position is confirmed by the band at $234 \mathrm{~nm}$ over all catalysts, which is the only band for Fe 0.6 -MFI-60-IE [30]. However, for $\mathrm{Fe}_{0.6}-\mathrm{MFI}-45-\mathrm{HS}$, the main band is at $220 \mathrm{~nm}$ and is assigned to framework $\mathrm{Fe}^{(+\mathrm{III})}$ species 
[31]. The framework $\mathrm{Fe}^{(+\mathrm{III})}$ species of $\mathrm{Fe}_{0.6}$-MFI-60-PS zeolite are shown at $272 \mathrm{~nm}$, which are often observed at this wavelength after preparation by isomorphous substitution and particularly for post-synthesis treatments [29,32]. Furthermore, the contribution of nanoclusters $\mathrm{Fe}^{(+\mathrm{II})} \mathrm{Ox}$ was found at $380 \mathrm{~nm}$ [33] over this material and with a very low

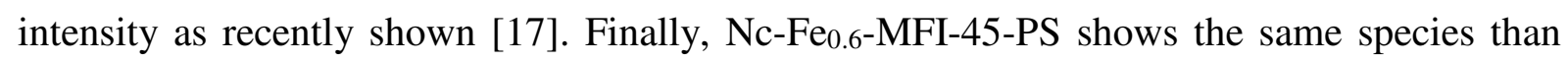
$\mathrm{Fe}_{0.6}$-MFI-60-PS but extra-framework species and particularly iron oxides (380 and $512 \mathrm{~nm}$ ) are more prominent on this zeolite.

\subsection{Catalytic tests}

\subsubsection{Influence of the preparation procedures and iron species}

Firstly, the influence of preparation procedures was tested over materials with the same crystallite size and iron content $(0.6$ wt.\%). Initially, all iron zeolites are very active, with a glycerol conversion still above 94\% after 30 min (Table 3 and supplementary Fig. S3). Over time, catalysts deactivate and differentiate each other. Fe 0.6 -MFI-45-HS prepared by hydrothermal synthesis deactivates much faster with a glycerol conversion of $58 \%$ after $8 \mathrm{~h}$. Conversely, post-synthesis preparations result in a slower deactivation and only slight differences are observed at the same time on stream (8h) with glycerol conversion of 80,87 , and $90 \%$ for $\mathrm{Fe}_{0.6}$-MFI-60-IE, $\mathrm{Fe}_{0.6}$-MFI-60-PS and $\mathrm{Fe}_{0.6}$-MFI-60-Imp respectively.

Whatever the catalyst, acrolein and acrylic acid are the main reaction products, acetol and acetaldehyde are observed as by-product, but in small amounts (Table S1). Carbon balance is higher than $80 \%$ and the undetected products are probably those of the gaseous phase, which should correspond to overoxidation into $\mathrm{CO}_{2}$. A similar trend is observed about acrolein

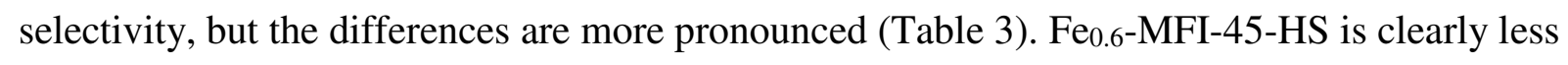
selective to acrolein compared to more selective Fe $_{0.6}$-MFI-60-IE, Fe ${ }_{0.6}$-MFI-60-Imp and especially $\mathrm{Fe}_{0.6}$-MFI-60-PS with a stable value of $82 \%$ after $8 \mathrm{~h}$ on stream. However, $\mathrm{Fe}_{0.6^{-}}$ MFI-45-HS is the most selective catalyst to acrylic acid (46\% at $8 \mathrm{~h}$ ) before $\mathrm{Fe}_{0.6}$-MFI-60-IE, $\mathrm{Fe}_{0.6}$-MFI-60-Imp and finally $\mathrm{Fe}_{0.6}$-MFI-60-PS with barely 9\%. These results exhibit that the catalytic behaviour in glycerol oxidehydration is clearly influenced by the preparation procedures of iron zeolites, which probably lead to the different iron species. It seems that extra-framework iron species, mostly present over post-synthetic zeolites ( $\mathrm{Fe}_{0.6}-\mathrm{MFI}-60-\mathrm{IE}$, $\mathrm{Fe}_{0.6}$-MFI-60-Imp and $\mathrm{Fe}_{0.6}$-MFI-60-PS), are the most active sites for glycerol conversion and that $\mathrm{Fe}^{(+\mathrm{II})} \mathrm{Ox}$ species, only observed over $\mathrm{Fe}_{0.6}$-MFI-60-PS, are probably the privileged sites responsible of selectivity to acrolein [17]. Contrariwise, the formation of acrylic acid 
seems to be promoted by $\mathrm{Fe}^{(+\mathrm{III})}$ species (and especially framework ones), which are numerous on $\mathrm{Fe}_{0.6}$-MFI-45-HS zeolite [18].

\subsubsection{Reduction of the crystallite size}

With a view to increase the catalytic performance of iron zeolites, it was decided to reduce the crystallites size in order to generate a greater available external surface (able to enhance activity and selectivity [17] and a greater amount of accessible extra-framework iron supposedly more active for glycerol dehydration. Nanocrystalline iron zeolite ( $\mathrm{Nc}-\mathrm{Fe}_{0.6}-\mathrm{MFI}-$ 45-PS) was then tested after preparation by fluoride treatment, which is the procedure that provides the most stable glycerol conversion.

Despite a very high coke content measured after $8 \mathrm{~h}$ of reaction (about $10 \mathrm{wt} . \% \mathrm{C}$ on both $\mathrm{Nc}$ -

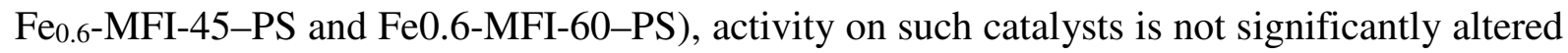
by heavy coking. As it was already proposed, interaction of iron particles with surface carbonaceous deposits could be involved in the formation of active species [17]. Indeed, Fig.4 confirms that $\mathrm{Nc}-\mathrm{Fe}_{0.6}$-MFI-45-PS, which exhibits the greater external surface, is even more stable than $\mathrm{Fe}_{0.6}$-MFI-60-PS. With a stabilized conversion of $90 \%$ and an acrolein yield of $80 \%$ ( $87 \%$ selectivity) after $24 \mathrm{~h}$ on stream, it proves to be a very active, selective and stable catalyst.

\section{Conclusion}

The oxidative dehydration of glycerol was performed over iron MFI zeolites with high Si/Al ratio (45-60) and $0.6 \mathrm{wt} . \%$ of iron prepared by different preparation procedures. These catalysts are mainly selective to acrolein and acrylic at $320^{\circ} \mathrm{C}$ under air. Thanks to $\mathrm{Fe}^{(+\mathrm{III})}$ tetrahedral species in framework position generated by hydrothermal synthesis preparation, $\mathrm{Fe}_{0.6}$-MFI-45-HS is more selective to acrylic acid. Conversely, post-synthesis preparations are more selective to acrolein especially fluoride medium treatment that promotes $\mathrm{Fe}^{(+\mathrm{II})} \mathrm{Ox}$ species formed by autoreduction of framework iron (Fe $\left.\mathrm{F}_{0.6}-\mathrm{MFI}-60-\mathrm{PS}\right)$. The reduction of crystallite size (and the enhancement of the external surface) with $\mathrm{Nc}-\mathrm{Fe}_{0.6}-\mathrm{MFI}-45$ led to one of the most stable system to date with only $7 \%$ of deactivation, a $90 \%$ glycerol conversion and $87 \%$ selectivity in acrolein after $24 \mathrm{~h}$ on stream.

\section{Acknowledgements}


Modibo Mounguengui Diallo gratefully acknowledges the French Higher Education and Research Ministry for his $\mathrm{PhD}$ grant. The authors make a point of thanking the European Communities (FEDER) as well as the presidency of the Poitou-Charentes region for their financial support. The authors thank Ms Nadia Guignard for UV-vis analysis.

Conflict of interest: The authors declare no conflict of interest.

\section{References}

[1] M. Besson, P. Gallezot, C. Pinel, Chem. Rev. 114 (2014) 1827-1870.

[2] F. Jerome, Y. Pouilloux, J. Barrault, Chemsuschem 1 (2008) 586-613.

[3] A. Talebian-Kiakalaieh, N.A.S. Amin, H. Hezaveh, Renew. Sustain. Energy Rev. 40 (2014) 28-59.

[4] T. Jekewitz, N. Blickhan, S. Endres, A. Drochner, H. Vogel, Catal. Commun. 20 (2012) $25-28$.

[5] P. Kampe, L. Giebeler, D. Samuelis, J. Kunert, A. Drochner, F. Haass, A.H. Adams, J. Ott, S. Endres, G. Schimanke, T. Buhrmester, M. Martin, H. Fuess, H. Vogel, Phys. Chem. Chem. Phys. 9 (2007) 3577-3589.

[6] Y. Gu, N. Cui, Q. Yu, C. Li, Q. Cui, Appl. Catal. A-Gen. 429 (2012) 9-16.

[7] Y.T. Kim, K.-D. Jung, E.D. Park, Microporous Mesoporous Mater. 131 (2010) 28-36.

[8] C.-J. Jia, Y. Liu, W. Schmidt, A.-H. Lu, F. Schueth, J. Catal. 269 (2010) 71-79.

[9] L. Lakiss, F. Ngoye, C. Canaff, S. Laforge, Y. Pouilloux, Z. Qin, M. Tarighi, K. Thomas, V. Valtchev, A. Vicente, L. Pinard, J.-P. Gilson, C. Fernandez, J. Catal. 328 (2015) 165-172.

[10] H. Zhang, Z. Hu, L. Huang, H. Zhang, K. Song, L. Wang, Z. Shi, J. Ma, Y. Zhuang, W. Shen, Y. Zhang, H. Xu, Y. Tang, Acs Catal. 5 (2015) 2548-2558.

[11] B.O. Dalla Costa, M.A. Peralta, C.A. Querini, Appl. Catal. A 472 (2014) 53-63.

[12] C.F. Pestana, A.C.O. Guerra, G.B. Ferreira, C.C. Turci, J.. Mota, JBraz Chem Soc (2013) 100-105.

[13] W. Zhang, B. Wang, J. Yang, P. Rui, N. Fan, W. Liao, X. Shu, Catal. Commun. 110 (2018) 97-101.

[14] G.M. Lari, C. Mondelli, J. Pérez-Ramirez, Acs Catal. 5 (2015) 1453-1461. 
[15] G. Sanchez, B.Z. Dlugogorski, E.M. Kennedy, M. Stockenhuber, Appl. Catal. A-Gen. 509 (2016) 130-142.

[16] P. Boron, L. Chmielarz, J. Gurgul, K. Latka, B. Gil, J.-M. Krafft, S. Dzwigaj, Catal. Today 235 (2014) 210-225.

[17] M.M. Diallo, S. Laforge, Y. Pouilloux, J. Mijoin, Catal. Lett. 148 (2018) 2283-2303.

[18] M.M. Diallo, J. Mijoin, S. Laforge, Y. Pouilloux, Catal. Commun. 79 (2016) 58-62.

[19] J.C. Xia, D.S. Mao, B. Zhang, Q.L. Chen, Y. Tang, Catal. Lett. 98 (2004) 235-240.

[20] S. Han, K. Schmitt, S. Schramm, D. Shihabi, C. Chang, Inorganica Chim. Acta 229 (1995) 81-85.

[21] M. Guisnet, P. Ayrault,J. Datka, Polish Jour. Chem. 71 (1997) 1455-1461

[22] S. Dzwigaj, N. Popovych, P. Kyriienko, J.-M. Krafft, S. Soloviev, Microporous Mesoporous Mater. 182 (2013) 16-24.

[23] M. Schwidder, M.S. Kumar, U. Bentrup, J. Pérez-Ramirez, A. Brueckner, W. Gruenert, Microporous Mesoporous Mater. 111 (2008) 124-133.

[24] R.J. Gorte, Catal. Lett. 62 (1999) 1-13.

[25] P. Sazama, N.K. Sathu, E. Tabor, B. Wichterlova, S. Sklenak, Z. Sobalik, J. Catal. 299 (2013) 188-203.

[26] J. Pérez-Ramirez, G. Mul, F. Kapteijn, J.A. Moulijn, A.R. Overweg, A. Domenech, A. Ribera, I. Arends, J. Catal. 207 (2002) 113-126.

[27] S. Dzwigaj, J. Janas, T. Machej, M. Che, Catal. Today 119 (2007) 133-136.

[28] N. Machado, V. Calsavara, N.G.C. Astrath, U.K. Matsuda, A. Paesano, M.L. Baesso, Fuel 84 (2005) 2064-2070.

[29] I. Hnat, I. Kocemba, J. Rynkowski, T. Onfroy, S. Dzwigaj, Catal. Today 176 (2011) $229-233$.

[30] J. Pérez-Ramirez, J.C. Groen, A. Brückner, M.S. Kumar, U. Bentrup, M.N. Debbagh, L.A. Villaescusa, J. Catal. 232 (2005) 318-334.

[31] S. Bordiga, R. Buzzoni, F. Geobaldo, C. Lamberti, E. Giamello, A. Zecchina, G. Leofanti, G. Petrini, G. Tozzola, G. Vlaic, J. Catal. 158 (1996) 486-501.

[32] P. Wu, T. Komatsu, T. Yashima, Microporous Mesoporous Mater. 20 (1998) 139-147.

[33] M.S. Kumar, M. Schwidder, W. Grunert, A. Brückner, J. Catal. 227 (2004) 384-397. 


\section{Tables captions}

Table 1. Textural properties of iron zeolites.

Table 2. Iron content and acidity of the different catalysts

Table 3. Glycerol conversion, acrolein and acrylic acid selectivities after 30min and $8 \mathrm{~h}$ (values in parentheses) on stream. 
Table 1. Textural properties of iron zeolites.

\begin{tabular}{lcccc}
\hline Catalyst & $\begin{array}{c}\text { BET } \\
\text { surface area } \\
\left(\mathbf{m}^{\mathbf{2}} \mathbf{g}^{-\mathbf{1}}\right)\end{array}$ & $\begin{array}{c}\text { External } \\
\text { surface area } \\
\left(\mathbf{m}^{\mathbf{2}} \mathbf{g}^{-1}\right)\end{array}$ & $\begin{array}{c}\text { Micropore } \\
\text { volume } \\
\left(\mathbf{c m}^{\mathbf{3}} \mathbf{g}^{-1}\right)\end{array}$ & $\begin{array}{c}\text { Mesopore } \\
\text { volume } \\
\left(\mathbf{c m}^{\mathbf{3}} \mathbf{g}^{-1}\right)\end{array}$ \\
\hline Fe0.6-MFI-45-HS & 445 & 76 & 0.16 & 0.09 \\
Fe0.6-MFI-60-PS & 381 & 54 & 0.15 & 0.09 \\
Fe0.6-MFI-60-IE & 401 & 49 & 0.16 & 0.08 \\
Fe0.6-MFI-60-Imp & 378 & 37 & 0.16 & 0.08 \\
Nc-Fe0.6-MFI-45-PS & 469 & 88 & 0.16 & 0.20 \\
\hline
\end{tabular}


Table 2. Iron content and acidity of the different catalysts.

\begin{tabular}{lcccc}
\hline Catalyst & $\begin{array}{c}\text { Iron } \\
\text { content } \\
(\text { wt.\% })\end{array}$ & $\begin{array}{c}\text { Total } \\
\text { acidity } \\
\left(\mu \mathrm{mol} \mathrm{g}^{-1}\right)^{\mathbf{a}}\end{array}$ & $\begin{array}{c}\text { Brønsted } \\
\text { acidity } \\
\left(\mu \mathrm{mol} \mathrm{g}^{-1}\right)^{\mathbf{b}}\end{array}$ & $\begin{array}{c}\text { Lewis } \\
\text { acidity } \\
\left(\mu \mathbf{m o l ~ g}^{-1}\right)^{\mathbf{b}}\end{array}$ \\
\hline Fe0.6-MFI-45-HS & 0.60 & 402 & 198 & 50 \\
Fe0.6-MFI-60-PS & 0.62 & 301 & 155 & 17 \\
Fe0.6-MFI-60-IE & 0.64 & 199 & 136 & 28 \\
Fe0.6-MFI-60-Imp & 0.60 & 231 & 145 & 38 \\
Nc-Fe0.6-MFI-45-PS & 0.58 & 310 & 166 & 78 \\
\hline
\end{tabular}

a: measured by $\mathrm{NH}_{3}$ thermodesorption

${ }^{\mathrm{b}}$ : measured by pyridine adsorption followed by infrared spectroscopy 
Table 3. Glycerol conversion, acrolein and acrylic acid selectivities after $30 \mathrm{~min}$ and $8 \mathrm{~h}$ (values in parentheses) on stream.

\begin{tabular}{lccc}
\hline Catalyst & $\begin{array}{c}\text { Glycerol } \\
\text { conversion }(\%)\end{array}$ & $\begin{array}{c}\text { Acrolein } \\
\text { selectivity (\%) }\end{array}$ & $\begin{array}{c}\text { Acrylic acid } \\
\text { selectivity (\%) }\end{array}$ \\
\hline Fe0.6-MFI-60-PS & $99(87)$ & $96(82)$ & $0(9)$ \\
Fe0.6-MFI-60-IE & $94(80)$ & $92(69)$ & $0(16)$ \\
Fe0.6-MFI-60-Imp & $99(90)$ & $90(65)$ & $0(18)$ \\
Fe0.6-MFI-45-HS & $96(58)$ & $71(32)$ & $24(47)$ \\
\hline
\end{tabular}




\section{Figures Captions}

Figure 1. XRD patterns of calcined MFI zeolite (calculated from crystallographic data, a), Fe0.6-MFI-45-HS (b), Fe0.6-MFI-60-Imp (c), Fe0.6-MFI-60-IE (d), Fe0.6-MFI-60-PS (e) and Nc-Fe0.6-MFI-45-PS (f) zeolites.

Figure 2. TPR profile of $\mathrm{Fe}_{0.6}$-MFI-45-HS, Fe $\mathrm{F}_{0.6} \mathrm{MFI}-60-\mathrm{PS}, \mathrm{Fe}_{0.6}-\mathrm{MFI}-60-\mathrm{IE}$ and $\mathrm{Fe}_{0.6} \mathrm{MFI}-$ 60-Imp zeolites.

Figure 3. UV-vis profile of $\mathrm{Fe}_{0.6}$-MFI-45-HS, Fe $\mathrm{F}_{0.6}$-MFI-60-IE, Fe $\mathrm{F}_{0.6} \mathrm{MFI}-60-\mathrm{PS}$, and Nc$\mathrm{Fe}_{0.6}$-MFI-45-PS zeolites.

Figure 4. Glycerol conversion (empty symbols) and acrolein yield (full symbols) over $\mathrm{Fe}_{0.6^{-}}$ MFI-60-PS ( $O$ ) and Nc-Fe $0.6-\mathrm{MFI}-45-\mathrm{PS}(\square)$ versus time on stream at $320{ }^{\circ} \mathrm{C}$ in air $(15$ $\left.\mathrm{mL} \min ^{-1}\right)$. 


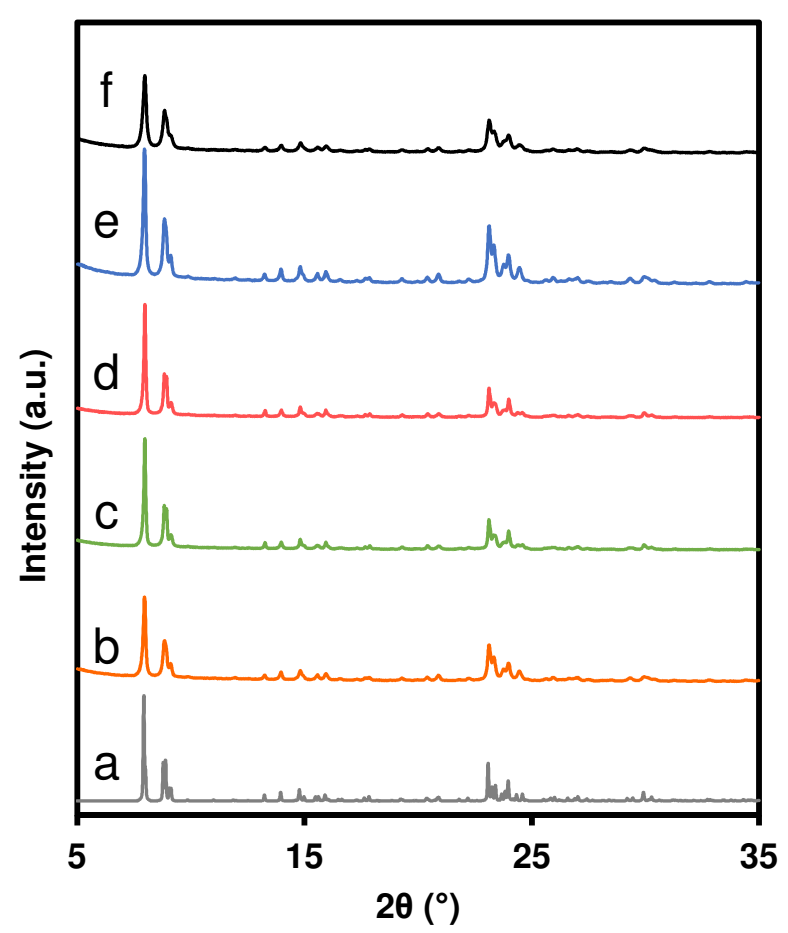

Figure 1. XRD patterns of calcined MFI zeolite (calculated, a), Fe0.6-MFI-45-HS (b), Fe0.6MFI-60-Imp (c), Fe0.6-MFI-60-IE (d), Fe0.6-MFI-60-PS (e) and Nc-Fe0.6-MFI-45-PS (f) zeolites.. 


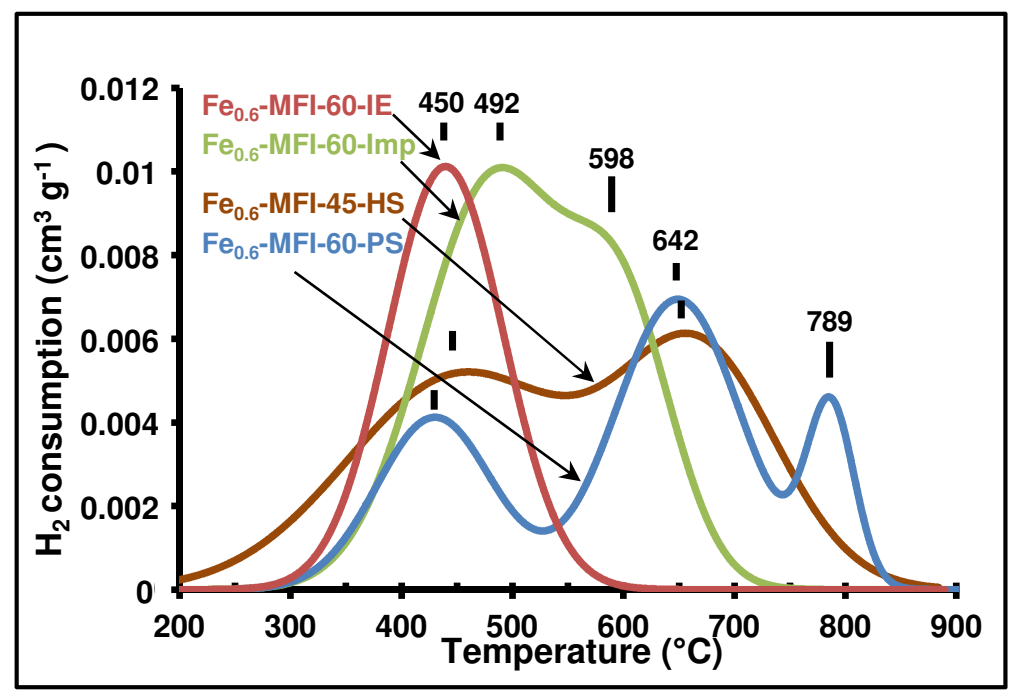

Figure 2. TPR profile of $\mathrm{Fe}_{0.6}$-MFI-45-HS, Fe $\mathrm{e}_{0.6}$-MFI-60-PS, Fe ${ }_{0.6}-\mathrm{MFI}-60-\mathrm{IE}$ and $\mathrm{Fe}_{0.6}$-MFI60-Imp zeolites. 


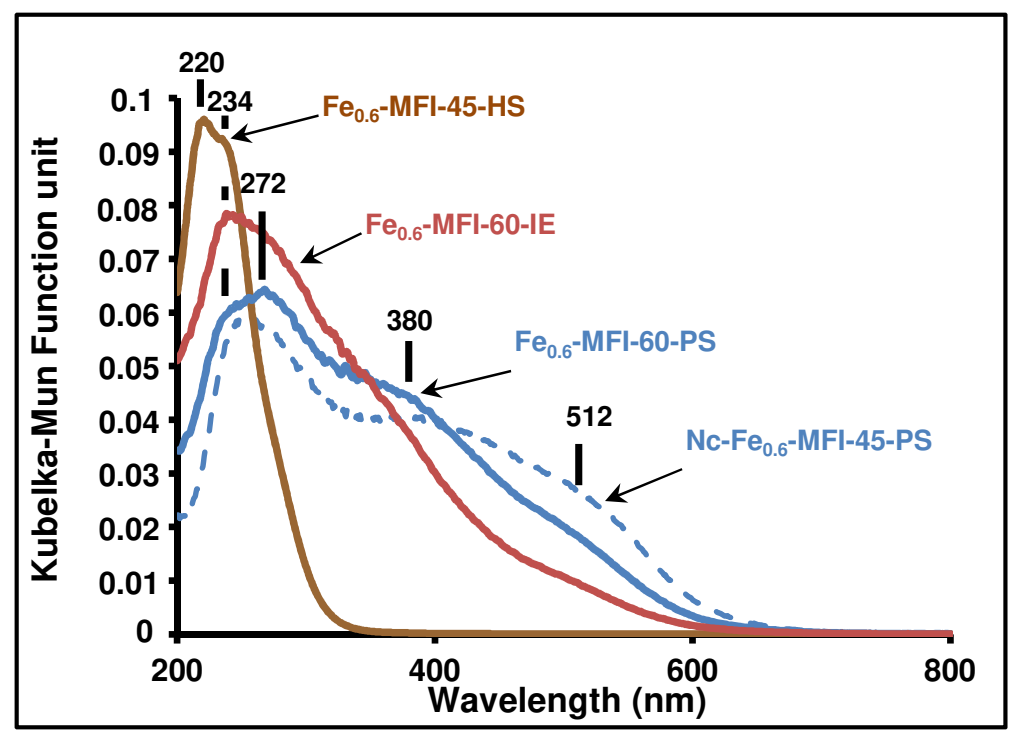

Figure 3. UV-vis profile of $\mathrm{Fe}_{0.6}$-MFI-45-HS, Fe $\mathrm{F}_{0.6} \mathrm{MFI}-60-\mathrm{IE}, \mathrm{Fe}_{0.6}$-MFI-60-PS, and Nc$\mathrm{Fe}_{0.6-\mathrm{MFI}}$-45-PS zeolites. 


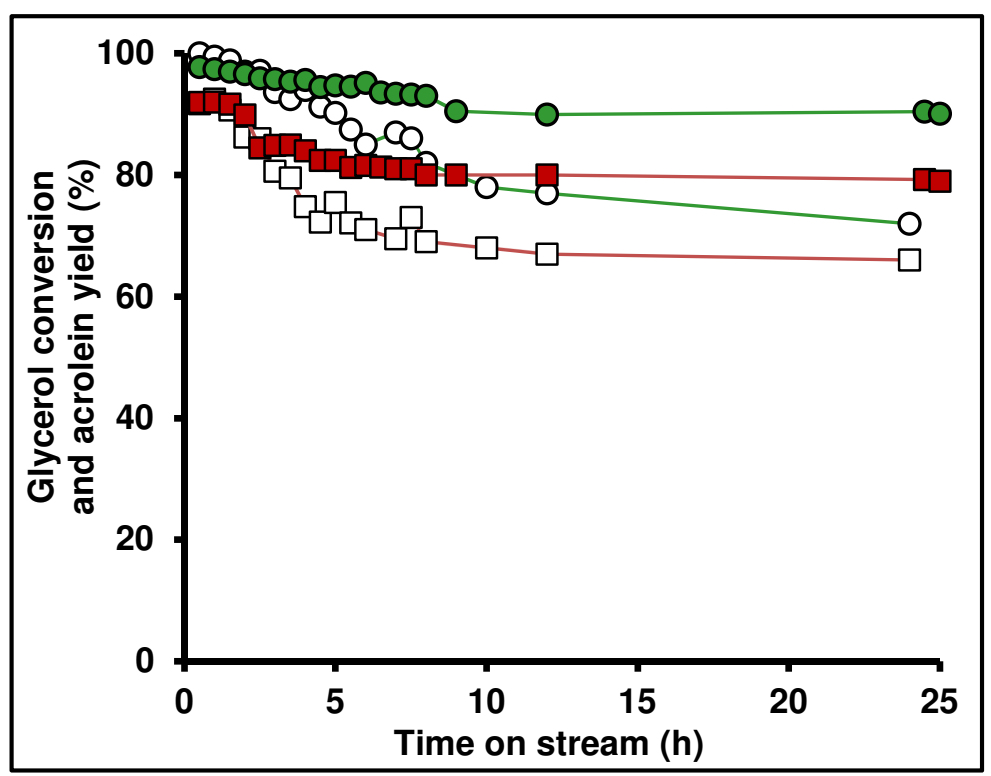

Figure 4. Glycerol conversion ( $O$ ) and acrolein yield ( $\square$ ) over $\mathrm{Fe}_{0.6}$-MFI-60-PS (empty symbols) and $\mathrm{Nc}-\mathrm{Fe}_{0.6}$-MFI-45-PS (full symbols) versus time on stream at $320^{\circ} \mathrm{C}$ in air $(15$ $\mathrm{mL} \min ^{-1}$ ). 

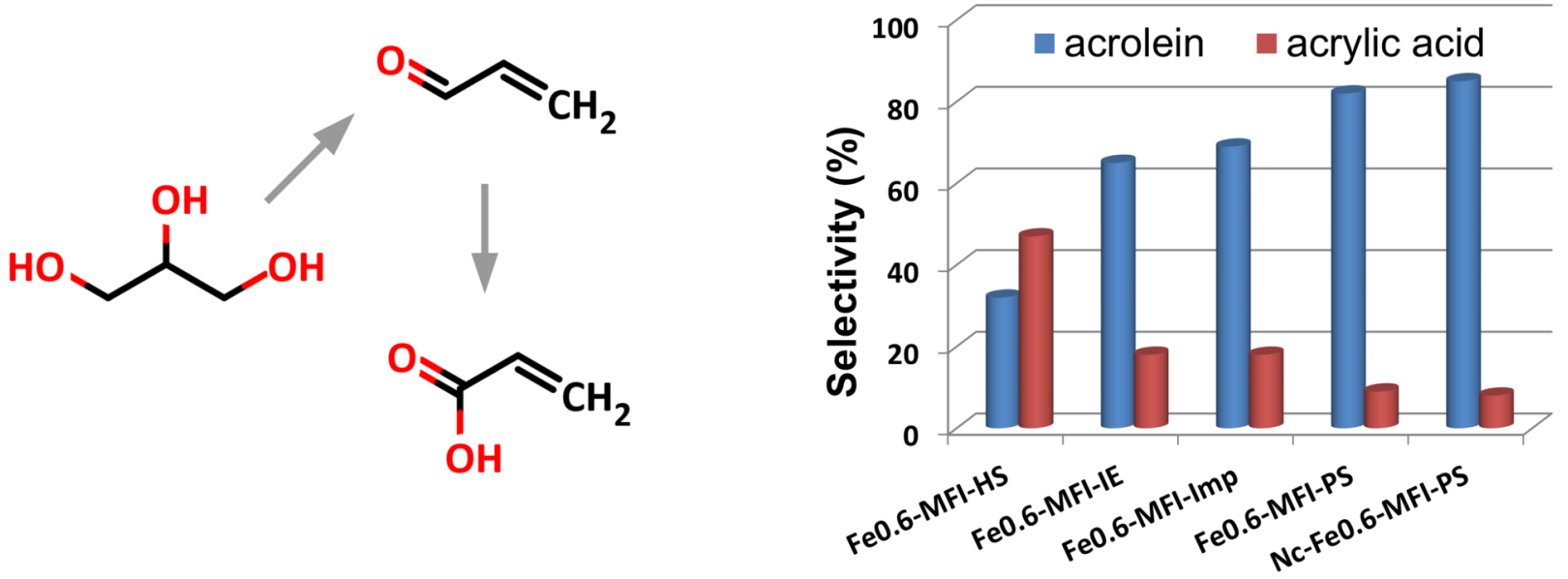